\title{
TYÖHÖN PALUU TRAUMAATTISEN SURUN JÄLKEEN
}

\section{Johdanto}

Traumaattista surua on oman lapsen kuolema, läheisen itsemurha tai kuolema väkivallanteon seurauksena sekä työikäisen puolison menettäminen. Kukin suree tavallaan mutta yhteisten lainalaisuuksien mukaisesti. Suru on aina raskasta. Traumaattisen surun poikkeavuus läheisen aikuisen menettämiseen liittyvästä tavanomaisemmasta surusta on tunnistettu, ja erona on todettu traumaattisen surun syvyys ja pitkäkestoisuus. Ylipäätään surulta puuttuu määräaika monessakin mielessä. Läheisen aikuisen kuolemasta seuraavan surutyön kesto on keskimäärin puoli vuotta, traumaattinen suru on vuosikausien prosessi. Traumaattinen suru aiheuttaa pitkäaikaista toimintakyvyn heikentymistä.

Surun taloudelliset vaikutukset työnantajalle ovat mittavia, etenkin kun huomioidaan tekijät, jotka estävät surevaa suremasta tai vaativat surun piilottelua työpaikalla. Surun vaikutusten laajuutta ei välttämättä ymmärretä, ja sen vaikutuksista työpaikkaan tai -yhteisöön tiedetään melko vähän (Hazen 2008). Työpaikoilla kuitenkin kohdataan läheisen kuoleman aiheuttamaa surua, ja voidaan sanoa, että jokainen johtaja kohtaa surevan työntekijän jossakin vaiheessa. Yhdysvaltalainen tutkija Bento (1994) toteaa läheisen kuoleman aiheuttaman surun koskettavan vuosittain arviolta 16 prosenttia työntekijöistä. Traumaattisen surun kohtaa vuosittain muutama prosentti surijoista (Genevro 2004).

Katsauksessa perehdytään traumaattisen surun kokeneen työntekijän työhön paluuseen. Tarkoituksena on tarkastella surevien kokemusten kautta traumaattisen surun vaikutusta surevaan ja työorganisaatioiden suhtautumista surevan palatessa työhön sekä kartoittaa käytänteitä työnantajan avuksi. Katsaus perustuu Tampereen yliopiston yhteiskunta- ja kulttuuritieteiden työn ja hyvinvoinnin maisteritutkinnon pro gradu -tutkielmaan. Aineisto kerättiin haastattelemalla traumaattisen surun kokeneita ihmisiä sekä jäsenkuntaansa edustavia surujärjestöjen toiminnanjohtajia. Tutkielmassa käytettiin kvalitatiivisen tutkimusotteen kerronnallista haastattelua. Suomessa toimii neljä surujärjestöä, joista Surunauha ry tukee itsemurhan tehneiden läheisiä, KÄPY Lapsikuolemaperheet ry lapsikuoleman kokeneita perheitä, Huoma ry henkirikoksessa läheisensä menettäneitä ja Suomen nuoret lesket ry työikäisiä leskiä. Katsaus liittyy myös Kuntoutussäätiön ja surujärjestöjen hankeyhteistyöhön.

\section{Traumaattinen suru}

Surutyö edellyttää tunnepohjaista, psykologista ja etenkin henkistä työtä (Bento 1994). Surevan on löydettävä uusi tapa yhteyden säilyttämiseen kuolleeseen. Esimerkiksi lapsensa menettänyt tottuu vähitellen vanhemmuuteen liittyvien velvoitteiden poistumiseen ja suhde muuttuu muistojen ja mielikuvien tasolla olevaksi muistosuhteeksi. Lapsi säilyy vanhemmilleen perheenjäsenenä kuoltuaankin. 
Surutyöhön kuuluu suruun ja menetykseen palaaminen uudestaan ja uudestaan, se vaatii myös taukoja. Surutyö kestää kauan ja vaatii paljon. (Poijula 2002.) Sureva jatkaa suhdetta kuolleeseen omassa sisäisessä maailmassaan, ja se maailma heijastelee surevan suhdetta niihin ihmisiin, joiden kanssa hän on tekemisissä. Yleensä suru muuttaa pysyvästi surevan persoonallisuutta ja vaikuttaa loppuelämän valintoihin. (Rubin 1999.)

Surutyö on käynnissä surevan palatessa takaisin työhön. Amerikkalainen Charles-Edwards (2009) on kehittänyt suruun liittyviä käytänteitä työnantajaorganisaatioiden avuksi. Hän kiteyttää työnantajien toimenpiteet surevan tukemiseksi osa-alueittain:

- Organisaatiossa on ymmärrettävä surun vaikutus surevaan ja tunteiden vaihteluista johtuvat ilmentymät työpaikalla.

- Työpaikan on eriteltävä tukitoimintonsa heti traumaattisen tapahtuman jälkeen ennen surevan paluuta.

- Työhön paluu on johdettava hallitusti.

- Työtovereiden tuki surevalle tapahtuman jälkeen tulee varmistaa, ja täytyy myös ymmärtää tapahtuneen vaikutus työyhteisöön.

- On järjestettävä pidempiaikainen tuki ja seuranta ja tunnettava surun vaiheet.

- Läheisen traumaattisen kuoleman vaikutukset surevan työhön ja muuhun elämään tulee selvittää.

- Lisäksi työnantajan tulee selvittää, miten pitää yhteyttä surevaan ja tämän perheeseen ja minkälaisia erityisvaateita tähän saattaa liittyä.

Todellisuuden ja suositusten vastaavuuden tarkastelu osoittaa, millaisia haasteita sureva kohtaa ja onko työnantajilla valmiuksia tukea työhön paluuta. Surevien kokemuksissa korostuivat surun vaikutusten ymmärtäminen, johdettu työhön paluu, työyhteisön tuki ja surevan työkyvyn ja jaksamisen kysymykset. Kirjallisuus käsittelee samoja aiheita ja nostaa esille tapoja, joita työpaikat voivat omaksua käytänteikseen.

Traumaattisen surun kohdanneita yhdistää eniten sosiaalinen eristäytyminen, joka johtuu ympäristön kyvyttömyydestä kohdata heitä. Traumaattinen suru ennustaa sosiaalista eristäytymistä mutta myös aiheuttaa sitä, vetäytyminen johtuu sosiaalisten verkostojen puutteellisesta kyvystä suhtautua surevaan. (Dyregrov ym. 2003.) Traumaattisen surun kokeneiden ihmisten sosiaaliset suhteet ovat vähäisiä ja heikkoja työhön paluun aikoihin. Traumaattisen surun kohdanneet haastateltavat kokivat eristäytyneensä, ja vuosien saatossa se oli johtanut lähes erakoitumiseen. Voidaan todeta, että keinot ja vakiintuneet käytännöt surevan kohtaamiseen puuttuvat eivätkä tuen tarve ja sen antaminen kohtaa.

Traumaattinen suru vie usein sairauslomalle. Kesto vaihtelee, osa on poissa työstä käytännön järjestelyjen kuten hautajaisten ajan, osa tarvitsee pidemmän ajan tai useampia taukoja. Sairausloma edellyttää diagnoosia. (Dyregrov \&t Dyregrov 2008.) Surujärjestöjen toiminnanjohtajien mukaan sairausloman perusteena käytetään yleensä masennusta, koska surun diagnoosi puuttuu. Masennusdiagnoosi ei kuvaa surevan tilannetta ja saattaa myöhemmin kääntyä haitaksi. Joidenkin haastateltujen kokemusten mukaan masennusdiagnoosin nimissä oleva pitkä sairausloma on esimerkiksi taloudellinen haitta silloin, kun sureva ei sen vuoksi saa lainoja tai henkivakuutuksia.

Saari (2000) toteaa, että traumaattiseen suruun saattaa liittyä depressiota ja sitä hoidetaan lääkkeillä. Masennusoireisiin tarkoitettu lääkitys vähentää oireita, mutta ei poista surun voimakkuutta. Tunteet pitää kohdata silloin kun ne tulevat, jotta suruaan voi työstää ja päästä siinä eteenpäin. Traumaattisen surun kokeneet haastateltavat tunsivat voimakasta ahdistuneisuutta ja myös masennusta työhön paluun aikaan, yhdellä oli diagnosoitu keskivaikea pysyvä masennus. Saaren (2000) mukaan tuen tarve on niin suuri, että sitä jaksetaan hakea, vaikka omat voimavarat koettaisiin muutoin erittäin heikoiksi.

\section{Työhön paluu}

Työnteko kuuluu työikäisen identiteettiin, ja tutkimusten perusteella surevaa tulee rohkais- 
ta työhön paluuseen melko pian tapahtuneen jälkeen. Työ tuo surevan päiviin muutakin sisältöä kuin suruun liittyvien asioiden käsittelyä. Työpaikan sosiaalinen tuki voisi auttaa surevaa, vaikka työhön paluu usein ahdistaa (Dyregrov \& Dyregrov 2008).

Johtajien ja esimiesten antama tuki on sattumanvaraista eli se riippuu sillä hetkellä töissä olevien toiminnasta. Silloin johdon empatia, oma kokemuspiiri ja arvot muokkaavat surevan saamaa tukea. (Charles-Edwards 2009.) Työorganisaation kulttuuri, politiikka ja käytänteet ohjaavat esimiestä, joten esimies tarvitsee organisaationsa tukea kyetäkseen toimimaan myötätuntoisesti (Hazen 2008). Vaikka organisaatio sallii poissaolon surun jälkeen, käy usein niin, että kun surevan huomioiminen korteilla, kukilla ja yhteydenotoilla on ohi ja kuvaannollinen olalle taputus tehty, niiden katsotaan riittävän osanoton osoitukseksi ja työntekijän oletetaan päässeen surun yli. Arki jatkuu, mutta surevan osalta kaikkea muuta kuin ennalta-arvattavasti. (Bento 1994.)

Haastattelujen perusteella työntekijän surun huomioon ottaminen jää työorganisaatiossa esimiehen ja työyhteisön tasolle. Haastateltujen työpaikoilla henkilöstöosasto ja yrityksen johto eivät reagoineet traumaattisen menetyksen kohdanneeseen surevaan, eikä tieto ilmeisesti aina kulje lähiesimieheltä eteenpäin. Myöskään työsuojeluorganisaatiot eivät näkyneet työhön paluun vaiheessa.

Sureva tarvitsee esimieheltään avointa keskustelua ja työkykyä varmistavien toimenpiteiden toteuttamista. Surevalle pitää osoittaa, että hän on arvostettu työyhteisön jäsen ja osa sen sosiaalista piiriä. Surevat kokivat kuormittavansa työyhteisöä saamiensa työnkevennysten ja joustojen vuoksi, ja tilannetta vaikeuttaa entisestään se, jos esimies muistuttelee asiasta, kuten yhdelle haastatellulle, pitkään osatyökykyisen statuksella olleelle surevalle oli käynyt. Kokemukset lähiesimiehen suhtautumisesta kertovat, että suru ohitettiin usein vain lyhyellä huomiolla. Sattumanvaraisuus lähiesimiehen suhtautumisessa oli ainoa surevien esimiehiä yhdistävä piirre.

\section{Työyhteisön tuki ja surun vaikutukset työyhteisöön}

Työyhteisön suurin resurssi on avoimuus. Surevan toiveita tulee kuunnella, ja työyhteisö osaa suhtautua varmemmin, jos se tietää, miten sureva toivoo tulevansa kohdelluksi. Ensimmäisen kerran surevan tavatessaan työtoverit voivat halata, osoittaa myötätuntoa ja kysyä surevan vointia. Työyhteisön tuki ja hyväksyvä vastaanottaminen on onnistuneen työhön paluun edellytys. Sureva pystyy kokemaan työhön liittyviä merkityksellisyyden tunteita, jos työyhteisö osoittaa empatiaa ja tietää surevaa kohdanneesta traumaattisesta surusta. Jos työtoveri ei tunne surevaa henkilöä riittävän hyvin tietääkseen, millaista tukea tämä haluaa, hän voi tukea niillä keinoilla, jotka itse arvioi hyviksi. (Dyregrov \& Dyregrov 2008.)

Työpaikalla ei usein tiedetä, mitä surevan käyttäytymisen ja jaksamisen osalta on odotettavissa, sillä kuolema on työelämäkontekstissa yhä tabu eikä sitä käsitellä yhteisesti. Liiallinen työmäärä ja erilaisten odotusten epämääräisyys voi aiheuttaa stressiä surevalle, ja seurauksena on uupumusta tai jopa irtisanoutuminen. Läheisen kuolema on jo sellaisenaan valtavan raskas taakka. (Bento 1994.) Työyhteisön ymmärtämättömyys ja huomioimattomuus surevaa kohtaan vaikeuttavat surun käsittelyä ja saattavat viedä surevan sairauslomalle (Dyregrov \& Dyregrov 2008).

Surevan käyttäytymiselle asetetut odotukset vaihtelevat työtehtävittäin. Potilaiden tai kenties surevien parissa töitä tekeviltä odotetaan omien tunteiden piilottamista. (Bento 1994.) Terveydenhoitoalalla työskentelevien haastateltujen kokemukset olivat identtisiä keskenään. He kokivat, että työyhteisö oli kyvytön kohtaamaan heidät, ja tämä kyvyttömyys mietitytti heitä yhä vuosia tapahtuneen jälkeen. Yksi haastateltu pohti, ovatko työntekijät aivan väärällä alalla, jos myötäeläminen häntä itseään kohtaa oli ollut olematonta: onko suhtautuminen asiakkaitakin kohtaan yhtä välinpitämätöntä?

Haastateltujen kokemusten perusteella surevan on vaikea arvioida surusta vaikenevan 
työyhteisön asennetta. Yksi haastateltu kertoi käyneensä työpaikkansa kaikissa naistenhuoneissa itkemässä, ja vaikka työpaikalla huomattiin hänen itkettynyt olemuksensa, asiaa ei koskaan otettu puheeksi. Surevat kokivat rasittavansa muita ja siksi vaikenivat surustaan. Haastatteluissa korostui, että surevat kokivat itselleen turvallisemmaksi olla jakamatta suruaan työyhteisössä. He kokivat kaipaavansa tukea mutta pelkäsivät joutuvansa itse toisten lohduttajaksi.

Työyhteisölle on olemassa hyviä ja yksinkertaisia käytänteitä, joilla se voi osoittaa välittävänsä surevasta ja huomioivansa tämän surua. Työtaakan vähentäminen ja työtehtäviin vaikuttaminen, yhteisiin sosiaalisiin tilanteisiin mukaan ottaminen ja ainakin kutsuminen, kuolleen mainitseminen ja herkkyys sekä kuunteluhalukkuuden osoittaminen ovat hyviä keinoja välittämisen osoittamiseksi. Työpaikalla ei tarvitse pelätä, että kuolleen puheeksi ottaminen nostaa mieleen surullisia tunteita, kuollut on joka tapauksessa surevan mielessä koko ajan. (Dyregrov \&t Dyregrov 2008.)

Haastatellut olivat miettineet jo ennen työhön paluutaan, miten työtoverit suhtautuvat heihin ja etenkin mitä he sanovat. Ne olivat myös pahimmat pelot, jotka osoittautuivat toteen lapsensa menettäneillä vanhemmilla. Työtoverit ja esimies esittivät loukkaavia kommentteja, ja jotkut olivat kokeneet jopa lapsen kuolemaan liittyvää työpaikkakiusaamista. Hienotunteisuuden ja välinpitämättömyyden raja on hiuksenhieno, jos työyhteisö ajattelee toimivansa hienotunteisesti jättämällä surun huomiotta. Tällöin surevaa ei suoranaisesti jätetä itsekseen, sen sijaan suhtautuminen jatkuu samanlaisena kuin ennen läheisen kuolemaa. Haasteltavat olivat kokeneet työyhteisön olevan kenties valmis tarjoamaan tukea mutta olevan epätietoinen keinoista.

\section{Surevan työkyky ja sen seuranta}

Surevan työkyky on pitkään työhön paluun jälkeen vaillinainen, ja tämä tulee ottaa huomioon. Mahdolliset ohjeistukset surevan työntekijän paluusta ja työnteosta kriisin jälkeen tulevat työterveyshuollolta, mutta sen tuottamat ohjeet ja käytänteet eivät riitä. Surevan kohtaamiseen liittyy myötäelämisen ja hienotunteisuuden osoittamisen vaatimuksia, jotka kohdistuvat sekä työpaikan johtoon että työntekijöihin. Välttely, ymmärtämättömyys ja se, ettei työolosuhteita muokata surevan tarpeiden mukaan, kuormittavat surevaa. (Dyregrov \&t Dyregrov 2008.) Kokemusten perusteella työterveyshuolto on usein ainoa suruun liittyvä taho. Yhteys sinne on yleensä surevan vastuulla.

Työnantaja ja etenkin esimies ovat ensisijaisesti vastuussa työntekijän työssä jaksamisesta. Työterveyshuollolle ei voi asettaa vastuuta työntekijän jaksamisen seuraamisesta ja tilanteeseen puuttumisesta tarvittaessa. (Virtanen Ct Sinokki 2014.) Tarjottava tuki hiipuu muutamassa kuukaudessa, mutta tuen tarve voi olla suurin silloin, kun tukea ei enää ole tarjolla. Työnantajalta edellytetään surevan jaksamisen seurantaa vielä pitkään surun aiheuttaneen tapahtuman jälkeen. (Charles-Edwards 2001.)

Tyypillisesti sureva yrittää tehdä työtä mahdollisimman hyvin, mutta tiedostaa aikaisempaa heikomman suorituskykynsä. Surevan pitäisi saada räätälöidä työtään ja työn kestoa työkykynsä mukaan. Työantajan kanssa pitäisi sopia, millaista työtä sureva tekee palatessaan työhön. Työn sisältöä on ehkä muutettava, ja esimerkiksi asiakaskontaktien osuutta on harkittava surevan voinnin mukaan. Tämän tyyppinen huomioiminen toimii palauttavana voimavarana. Ennallaan jatkuva tai liiallinen työn kuormittavuus uuvuttaa surevaa ja saattaa viedä uudelle sairauslomalle. Haastateltujen kokemusten mukaan esimies ei muokannut työtehtäviä surevalle, sen sijaan työyhteisön jäsenet saattoivat jakaa tehtäviä uudelleen helpottaakseen surevan jaksamista.

Työkyvyn heikentymisen kesto vaihtelee, ja on haastavaa arvioida, missä vaiheessa sureva kykenee täysipainoiseen työhön. Avoin keskusteluyhteys lähiesimiehen ja työntekijän välillä edistää molempien etuja. Sitä puoltaa myös se havaittu seikka, että sosiaalinen ympäristö ei tunnista surua, jos sen ilmentymät eivät näy selvästi. Työroolin turviin piilou- 
tuvan työntekijän oletetaan jaksavan ja pärjäävän, vaikka totuus olisi toinen. Avoimella keskustelulla vältetään myöhemmät turhat pohdinnat siitä, olisiko työssä romahtanut ja todellisen heikon vointinsa näyttänyt sureva osattu ohjata oikean avun piiriin.

Tukahdutetusta tai "äänioikeudettomasta" surusta seuraa helposti mielenterveydellisiä ongelmia, jotka voivat aiheuttaa huomattavia taloudellisia kuluja työnantajalle. Työnantaja menettää työntekijän työpanoksen, ja sen lisäksi poissaolosta aiheutuu sosiaalisia ja taloudellisia haittoja. On tärkeää kiinnittää huomiota siihen tapaan, jolla surevaan suhtaudutaan, surevan pystyvyyden käsityksiin ja surevan voinnin seuraamiseen. Suruprosessi laajenee ja pahenee, jos se ei saa edetä omaa luonnollista kulkuaan eikä suru pääse esille - suru jää ikään kuin äänioikeudettomaksi.

Sureva kaipaisi työntekoon liittyviä mittareita, joiden avulla selvitettäisiin hänen jaksamistaan ja työkykyään. Suomalaisilta työorganisaatioilta vaikuttaa puuttuvan malli surevan työkyvyn ja -tehon seuraamiseen.

Oman työsuorituksen laatu työhön paluun jälkeen askarrutti surevaa. Oman työsuorituksen arvioiminen oli vaikeaa, ja surevat olivat pelänneet sitä, olivatko he aiheuttaneet jopa potilasvahinkoja. Surevat kokivat, että esimiehet olivat antaneet heille liian vaativia työtehtäviä. Työn laatua ei seurattu työpaikalla, ja niin kauan kuin sureva pysyi työtahdissa ja suoritti tehtäviään, asia ei vaikuttanut kiinnostavan esimiehiä.

Työhön paluun oikea-aikaisuuteen, jaksamiseen ja työkykyyn liittyvät kysymykset jäivät haastateltujen kokemusten perusteella selvittämättä. Työterveyshuolto tukee pitkältä sairauslomalta palaavaa, ja joissakin työorganisaatioissa toteutetaan työterveyshuollon, työnantajan ja työntekijän kesken työntekijän työkyvyn tueksi kolmikantaneuvotteluja, joiden avulla pitkältä sairauslomalta palaava surevakin saattaa saada apua. Kahden haastatellun työpaikoilla oli käytössä kolmikantaneuvottelut, mutta kumpikaan ei tiennyt, miksei niitä toteutettu heidän kohdallaan.

\section{Johtopäätökset}

Traumaattisen surun käsittely on aina yksilöllistä, vaikka prosessiin sisältyy myös kaikille ihmisille yhteisiä piirteitä: samoja ajatuksia ja toimintoja. Traumaattisella surulla on pitkäkestoiset vaikutukset työntekoon. Ympäristöltään tukea ja ymmärrystä saava sureva palautuu ajan mittaan täyteen työkykyynsä. Surevan toiveena on olla samanlainen työntekijä kuin hän oli ennen läheisensä kuolemaa.

Sureva ei ole täysin toimintakykyinen työhön palatessaan. Työhön paluun ja surutyön samanaikaisuus kuormittavat surevaa. Surevien kokemusten perusteella työorganisaation johto ja henkilöstöosasto eivät näkyneet surevan työhön paluussa. Esimiehen ja työyhteisön suhtautuminen oli sattumanvaraista ja riippui työtovereiden kyvystä suhtautua surevaan. Sureva kaipaa tukea ja esimiehen ja työtovereiden osoitusta siitä, että häntä ymmärretään surevana eikä oleteta olevan samanlainen kuin ennen.

Suru on haastavaa työorganisaatiolle, koska se vaatii erilaisen suhtautumisen surevaan. Työorganisaatioilla ei useinkaan ole käytänteitä surevan huomioimiseen. Ongelmallista on, jos surulle ei ole sijaa työyhteisössä, koska työyhteisö on tottunut näkemään jäsenensä tietynlaisena eikä suhtautumista osata muuttaa. Jos suru jää työpaikalla äänioikeudettomaksi ja tunnistamattomaksi, siitä aiheutuu ongelmia, muun muassa työnantajalle taloudellisia menetyksiä.

Työnantajat tarvitsevat käytänteitä siihen tilanteeseen, kun sureva palaa työhön. Sureva on erilainen kuin ennen, käyttäytyy eri tavalla ja hänen työkykynsä vaihtelee voimakkaasti. Etenkin sosiaalisen tuen merkitys on valtava, joten työpaikalla tulisi olla osaamista surevan kohtaamiseen. Traumaattisen surun kokevalle kaikki on paljon raskaampaa kuin tavanomaisemman surun kokevalle. Käytänteitä ja ohjeistusta tarvitaan yrityksen johdolle, esimiehelle ja työyhteisölle.

\section{Mariliinu AhIström, MBA}

Mika Ala-Kauhaluoma, YTT, yhteyspäällikkö, Kuntoutussäätiö 


\section{Lähteet}

Bento R (1994) When the Show Must Go on. Journal of Managerial Psychology 9:6, 35-44.

Charles-Edwards D (2001) Responding to bereavement at work. Bereavement Care 20:3, 41-42.

Charles-Edwards D (2009) Empowering People at Work in the Face of Death and Bereavement. Death Studies 33:5, 420-436.

Dyregrov K, Dyregrov A (2008) Effective Grief and Bereavement Support: The Role of Family, Friends, Colleagues, Schools and Support Professionals. London: Jessica Kingsley Publishers.

Dyregrov K, Nordanger D, Dyregrov A (2003) Predictors of psychosocial distress after suicide, SIDS and accidents. Death Studies 27, 143-165.

Genevro J (2004) Report on bereavement and grief research. Death Studies 28, 491-575.

Hazen M (2008) Grief and the workplace. The Academy of Management Perspectives 22, 78-86.

Poijula S (2002) Surutyö. Kirjapaja Oy, Helsinki.

Rubin S (1999) The two-track model of bereavement: Overview, retrospect and prospect. Death Studies 23:8, 681-714.

Saari S (2000) Kuin salama kirkkaalta taivaalta - kriisit ja niistä selviytyminen. Otava, Helsinki.

Virtanen P, Sinokki M (2014) Hyvinvointia työstä: työhyvinvoinnin kehittyminen, perusta ja käytännöt. Tietosanoma, Helsinki. 